\title{
IUGA-ICS terminology and standardization documents: maximal use offers maximum patient and academic benefit
}

\author{
Bernard Haylen
}

Received: 21 December 2012 / Accepted: 10 January 2013 / Published online: 30 January 2013

(C) The International Urogynecological Association 2013

An article by Freeman et al. [1] in this issue illustrates both the importance and the benefits of using the International Urogynecological Association (IUGA)/International Continence Society (ICS) terminology and standardization documents produced over recent years [2-5]. The first three [2-4] documents are used and referenced, with reference 5 published subsequently and not specifically relevant to the study.

Clarity of terminology is ensured by use of the IUGAICS terminology for female pelvic floor dysfunction [2] This is acknowledged at the end of the "Methods" section by the statement "methods, definitions and units conform to the standards jointly recommended by IUGA and ICS, except where specifically noted." There is, as a result, a minimal chance of misinterpretation of terminology by either referee or reader.

The objective and subjective outcomes are stated, at the start of the "Methods" and the "Results" sections, to be in keeping with the "IUGA/ICS recommendations for reporting outcomes in surgical procedure for pelvic organ prolapse (POP)" [3]. That document [4] itself collates a range of other relevant outcome scales. This should result in the uniform use of outcome measures enabling meta-analyses and highquality systematic reviews to provide evidence-based management for patients.

In addition to the recent IUGA-ICS documents, Freeman et al. [1] quote and use - in the study and analysis - an earlier document, the Pelvic Organ Quantification (POP-Q) system [6], a summary of which is contained in the article by Haylen et al. [2].

B. Haylen $(\bowtie)$

University of New South Wales, 904/438 Victoria Street,

2010, Darlinghurst, NSW, Australia

e-mail: haylen@optusnet.com.au
All complications reported in the article by Freeman et al. [1] were carefully described and coded according to the IUGA-ICS Classification of Complications related directly to the insertion of prostheses and grafts [3]. Those complications at the 12-month review were not that many overall. Intraoperative complications included bladder injury (Code 4A T1 S5), bowel trauma requiring resection (Code 5C T1 S5) and sacral hemorrhage (Code 7A T1S5). There were three cases of late dyspareunia (Code 1Bc T3 S5). There was thus maximal clarity for readers and referees in this recording of complications. The use of this classification [3] and the equivalent classification for native tissue surgery for POP [5] should help identify the true incidence and type of complications for all POP surgery and stress urinary incontinence.

As all procedures in Freeman et al.'s article [1] were sacrocolpopexies-by definition, involving the use of mesh - the equivalent IUGA-ICS Classification of Complications related to native tissue pelvic floor surgery [5] was not relevant. There will be many studies involving the comparison of mesh repairs and native tissue surgeries for pelvic organ prolapse. There are now IUGA-ICS classifications $[3,5]$ for complications arising from both scenarios, which will assist researchers and authors.

Freeman et al. [1] are therefore to be congratulated for their extensive use of the recent IUGA/ICS Terminology and Standardization documents. The benefits for their article are maximal clarity, particularly in the areas of (i) terminology for methods, definitions and units; (ii) the reporting of surgical outcomes; (iii) the reporting of complications. Overall, the article provides an excellent example to all authors submitting articles to this journal, particularly those related to surgical studies, in turn contributing to evidencebased management for patients. 
Conflicts of interest None.

\section{References}

1. Freeman RM, Pantazis K, Thomson A, Frappell J, Bombieri L, Moran P, Slack M, Scott P, Waterfield M (2012) A randomized controlled trial of abdominal versus laparoscopic sacrocolpopexy for the treatment of post-hysterectomy vaginal vault prolapse: LAS study. Int Urogynaecol J. doi:10.1007/s00192-012-1885-x

2. Haylen BT, Freeman RM, de Ridder D, Swift SE, Berghmans B, Lee J, Monga A, Petri E, Rizk D, Sand P, Schaer G (2010) An International Urogynecological Association (IUGA) - International Continence Society (ICS) joint report into the terminology for female pelvic floor dysfunction. Neurourol Urodyn 29:4-20, Int Urogynecol J, 21:5-26

3. Haylen BT, Freeman RM, Swift SE, Cosson M, Davila GW, Deprest J, Dwyer PL, Fatton B, Kocjancic E, Lee J, Maher C, Rizk DE, Petri E, Sand PK, Schaer GN, Webb R (2011) An International Urogynecological Association (IUGA)/International Continence
Society (ICS) Joint Terminology and Classification of complications related directly to the insertion of prostheses (meshes, implants, tapes) and grafts in female pelvic floor surgery. Int Urogynecol J 22:3-15, and Neurourol Urodyn, 30 (1):2-12

4. Toozs-Hobson P, Freeman R, Athanasiou S, Haylen BT, Barber M, Swift S, Maher C, De Ridder D, Whitmore K, Ghoniem G (2012) An International Urogynecological Association (IUGA)/ International Continence Society (ICS) joint report on the terminology for reporting outcomes of surgical procedures for pelvic organ prolapse. Int Urogynecol J 23(5):527-535, and Neurourol Urodyn (4):415-421

5. Haylen BT, Freeman RM, Swift SE, Cosson M, Deprest J, Dwyer PL, Fatton B, Kocjancic E, Lee J, Maher C, Rizk DE, Petri E, Schaer GN, Webb R (2012) An International Urogynecological Association (IUGA)/International Continence Society (ICS) joint terminology and classification of complications related native tissue female pelvic floor surgery. Int Urogynaecol J 23:527-535, and Neurourol Urodyn 31(4):406-414

6. Bump RC, Mattiasson A, Bo K, Brubaker LP, DeLancey JO, Klarskov P, Shull BL, Smith AR (1996) The standardization of terminology of female pelvic organ prolapse and pelvic floor dysfunction. Am J Obstet Gynecol 175(1):10-17 